\title{
Oirat Language
}

National Cancer Institute

\section{Source}

National Cancer Institute. Oirat Language. NCI Thesaurus. Code C154199.

A Mongolic language that is regarded as either a dialect of Mongolian or a distinct

language. 